\title{
FOOD AND FEEDING OF THE BLUE SWIMMER CRAB, PORTUNUS PELAGICUS (LINNAEUS, 1758) (DECAPODA, BRACHYURA) ALONG THE COAST OF MANDAPAM, TAMIL NADU, INDIA
}

\author{
BY \\ JOSE JOSILEEN ${ }^{1}$ ) \\ Central Marine Fisheries Research Institute, P.O. Box 1603, Cochin-682 018, India
}

\begin{abstract}
Food habits of the blue swimmer crab, Portunus pelagicus were investigated using specimens collected from trawl catches in the Mandapam region, Tamil Nadu, along the east coast of India $\left(9^{\circ} 20-25^{\prime} \mathrm{N} 79^{\circ} 5-10^{\prime} \mathrm{E}\right)$, during the period January to December, 1999. The stomach contents of 452 crabs, ranging from 61 to $180 \mathrm{~mm}$ carapace width, were analysed. Their diet included crustaceans, molluscs, fishes, unidentifiable matter, and debris. In adult crabs, crustaceans constituted the dominant food source and these were present in $78.43 \%$ of the stomachs analysed. The stomach contents of juveniles and sub-adults were dominated by debris. There was no significant difference between sexes in the frequency of occurrence of food items or in their "percentage points" [ $=$ the (virtual) percentual contribution to the fullness of a $100 \%$ full stomach]. However, there was a difference between the stomachs of ovigerous and non-ovigerous females. There were also significant differences in the preference for food items in the different size groups of the crab. The results collected from the present study showed that $P$. pelagicus exhibits, in this region at least, a clear preference for crustaceans.
\end{abstract}

\section{RÉSUMÉ}

Les habitudes alimentaires du crabe «étrille bleue », Portunus pelagicus ont été étudiées en utilisant des specimens collectés par prises an chalut dans la région de Mandapam, Tamil Nadu, le long de la côte orientale de $1^{\prime}$ Inde $\left(9^{\circ} 20-25^{\prime} \mathrm{N} 79^{\circ} 5-10^{\prime} \mathrm{E}\right)$, au cours de la période janvier à décembre 1999. Les contenus stomacaux de 452 crabs, de 61 à $180 \mathrm{~mm}$ de largeur de carapace, ont été analysés. Leur régime incluait des crustacés, des mollusques, des poissons, de la matière non identifiable et des débris. Chez les crabes adultes, les crustacés constituaient la source alimentaire dominante et ceux-ci étaient présents dans 78,43\% des estomacs analysés. Il n'y avait pas de différence significative entre les sexes dans la fréquence de présence des différents aliments ou dans leurs « percentage points 》 [ = la contribution en pourcentage (virtuelle) au remplissage d'un estomac plein à 100\%]. Cependant, il y avait une différence entre les estomacs des femelles ovigères et non-ovigères. Il y avait aussi des différences significatives dans la préférence pour les différents aliments dans les différents groupes de taille du crabe. Les résultats obtenus dans cette étude ont montré que $P$. pelagicus montre, dans cette région au moins, une préférence évidente pour les crustacés.

1) e-mail: drjoslin@gmail.com

(C) Koninklijke Brill NV, Leiden, 2011

Also available online: www.brill.nl/cr 


\section{INTRODUCTION}

Knowledge of the dietary habits of a species is essential for understanding its nutritional requirements and thus its interactions with other groups of animals. This information is also useful for its successful culture. Crabs include filter feeders, sand cleansers, mud, plant, and carrion feeders, predators, commensals, and parasites (Dall \& Moriarty, 1983). Crabs occupy many different niches and inhabit many different habitats in a variety of geographical areas, and this is reflected in the variety of food consumed by them (Chande et al., 1999; DahdouhGuebas et al., 1999; Kyomo, 1999; Bryceson \& Massinga, 2002).

Although Portunus pelagicus (Linnaeus, 1758) feeds on macroscopic food, identification of the various food items as well as a reliable estimate of their (relative) quantity, are both very difficult. The crab uses its mouthparts to chop the food into small pieces and then the gastric mill ossicles further reduce the food to unidentifiable fragments. The majority of researchers use the foregut contents to study the quantity and nature of the different food items the crab has consumed (Sukumaran \& Neelakandan, 1997; Williams, 1981; Chande \& Mgaya, 2003, 2004). Hynes (1950) reviewed the methods adopted in the analyses and further study of the food and feeding of fishes. Most of the studies on the food and feeding of other aquatic organisms are now based on Hynes' (1950) study. Natarajan \& Jhingran (1961) have discussed several methods of gut content analysis and describe an "Index of preponderance" (I) $\left[\mathrm{I}=\left(\mathrm{v}_{\mathrm{i}} \mathrm{O}_{\mathrm{i}}\right) /\left(\sum_{\mathrm{v}_{\mathrm{i}} \mathrm{O}_{\mathrm{i}}}\right) \times 100\right.$, where $v_{i}=$ volume percentage, and $o_{i}=$ occurrence percentage of food item $\left.i\right]$, as well as its scope and construction. This index provides a definite and measurable basis for grading the various food elements as it gives a combined picture of frequency of occurrence, as well as bulk.

Previous studies on crabs that report on the feeding and diet of various species already have provided some relevant data, which are, however, mostly incomplete and certainly can not be directly applied to the situation of Portunus pelagicus in the region here studied. George (1965) described the anatomy and histology of different parts of the digestive system of Portunus sanguinolentus (Herbst, 1783). Studies have been made on the morphology of the mouthparts, the structure of the gut, and the digestive physiology of the mud crab, Scylla serrata (Forskål, 1775) (cf. Barker \& Gibson, 1978). Jewett \& Feder (1982) analysed the food and feeding habits of the king crab, Paralithodes camtschaticus (Tilesius, 1815) near Kodiak Island, Alaska. The feeding habits of the blue crab, Callinectes spp., have been studied by several workers, e.g., Tagatz (1968), Paul (1981), Laughlin (1982), Stoner \& Buchanan (1990), and Rosas et al. (1994). The food of the tanner crab, Chionoecetes bairdi (M. J. Rathbun, 1924) was studied by Jewett \& Feder (1983) and that of Chionoecetes opilio (J. C. Fabricius, 1788) by Wieczorek \& 
Hooper (1995). Choy (1986) described the natural diet and feeding habits of two species of Liocarcinus, while those same features of Cancer spp. and Ovalipes ocellatus (Herbst, 1799) were dealt with by Stehlik (1993). The natural diet and feeding habits of Thalamita crenata (H. Milne Edwards, 1834) were investigated by Cannicci et al. (1996). There are several detailed reports on the food and feeding habits of Scylla serrata, i.e., those by Hill (1976, 1980), Williams (1978), Joel \& Raj (1986), and Prasad \& Neelakantan (1988). Finally, investigations on the diet and gut contents of Portunus spp. have been made by Hill (1980), Stephenson et al. (1982), Campbell (1984), Wassenberg \& Hill (1987), and Sumpton \& Smith (1990). Obviously, those reports last-mentioned comprise data that can be compared, at least to some degree, with the data here collected for P. pelagicus in Indian waters.

For several years now, Mandapam has been the major fishing ground for Portunus pelagicus in India. Despite its importance in these fisheries, however, there is no information on the diet and preferred food items of the species from this area. Recently, this crab was found to be a suitable species for aquaculture, and some information is now available on its life cycle and growth (Josileen \& Menon, 2004, 2005). Hence, the present study has been undertaken to investigate the food and feeding habits of $P$. pelagicus along the coast of Mandapam and probably the results of this study will be useful for developing successful farming techniques for this species in the future.

\section{MATERIAL AND METHODS}

For food and feeding studies, specimens of Portunus pelagicus were collected from the commercial catches of shrimp trawlers in the Mandapam area $\left(9^{\circ} 20\right.$ $\left.25^{\prime} \mathrm{N} 79^{\circ} 5-10^{\prime} \mathrm{E}\right)$. Samples were collected once a month for a period of one year continuously. Studies on food and feeding were carried out following a method adapted from Sukumaran (1995): after recording the carapace width and length and the total weight of the crab, the dorsal side of the body was cut open and the foregut was removed carefully. The fullness of the stomach was visually examined and assessed as $0,25,50,75$, or $100 \%$. The foreguts were preserved in $10 \%$ formalin for a week, prior to being cut open and their contents transferred into Petri dishes with distilled water. The food components of the gut contents were separated and identified under a compound microscope.

As is characteristic of brachyurans, most of the food items were found to be unidentifiable as a result of having been highly crushed and hence only the hard structures that could be identified were relied upon for determining food composition and further evaluation. Gut contents were broadly classified into five categories, as follows: 
1. Crustacean remains - penaeid shrimp appendages; body parts of crabs and crab eggs; isopod and stomatopod parts.

2. Fish remains - fins, scales, bones, and vertebrae.

3. Molluscan remains - parts of bivalve and gastropod shells.

4. Miscellaneous - algal filaments, nematodes, polychaetes, and unidentified items.

5. Debris — sand and mud.

Neither the quantity of food nor the food components were significantly different in males and females, and hence the food data for both sexes were combined. Only stomachs that contained food were considered for analysis and calculation.

For each specimen, the whole stomach content was segregated according to food-groups, and each group's contribution was determined visually. Dominance of food groups was evaluated by ranking them by their percentage frequency of occurrence and so-called percentage points (see further below). The percentage frequency of occurrence was estimated as:

\section{No. of stomachs with particular food group $\times 100$}

Total no. of stomachs with food

To estimate the volume of the food by food-group, points were assigned to each group as suggested by Stehlik (1993): to quote one example, a food group that formed $50 \%$ of the total food content of a stomach that was $50 \%$ full, was assigned 25 points $(50$ points $\times 0.50)$. Percentage points were thus estimated as:

Point of the particular food group $\times 100$

Total points of all food groups

\section{RESULTS}

The stomach contents of Portunus pelagicus appeared to consist mainly of crustaceans, molluscs, fish, large quantities of unidentifiable matter, and debris. Out of the 452 stomachs examined, $3.54 \%$ were $100 \%$ full; $19.91 \%$ were $75 \%$ full; $25.66 \%$ were $50 \%$ full; $26.77 \%$ were $25 \%$ full; and $24.1 \%$ were empty. The details by month and according to the size of the crabs are given in tables I and II.

Whenever food was found in any stomach, it always consisted of a mixture of various food groups. Upon analysis, it was found that the percentual frequency of occurrence of miscellaneous items comprised $83.09 \%$ of all cases; Debris $79.59 \%$; Crustaceans 78.43\%; Molluscs 59.48\%; and Fishes 56.27\% (table III). 
TABLE I

Stomach fullness during various months in Portunus pelagicus (L.)

\begin{tabular}{lcccccc}
\hline \multicolumn{7}{c}{ Number $(\%)$} \\
\cline { 2 - 7 } Month & Empty & $25 \%$ & $50 \%$ & $75 \%$ & Full & Total \\
\hline Jan. & $1(3.57)$ & $11(39.29)$ & $12(42.86)$ & $4(14.29)$ & 0 & 28 \\
Feb. & $7(15.56)$ & $14(31.11)$ & $14(31.11)$ & $4(8.89)$ & $6(13.33)$ & 45 \\
Mar. & $11(35.48)$ & $9(29.03)$ & $3(9.68)$ & $7(22.58)$ & $1(3.23)$ & 31 \\
Apr. & $6(11.76)$ & $16(31.37)$ & $10(19.61)$ & $19(37.25)$ & 0 & 51 \\
May & $7(43.75)$ & $3(18.75$ & $4(25.00)$ & $2(12.50)$ & 0 & 16 \\
Jun. & $9(21.43)$ & $9(21.43)$ & $12(28.57)$ & $10(23.81)$ & $2(4.76)$ & 42 \\
Jul. & $10(22.73)$ & $7(15.91)$ & $10(22.73)$ & $14(31.82)$ & $3(6.82)$ & 44 \\
Aug. & $5(23.81)$ & $3(14.29)$ & $9(42.86)$ & $3(14.29)$ & $1(4.76)$ & 21 \\
Sep. & $8(22.22)$ & $9(25.00)$ & $11(30.56)$ & $8(22.22)$ & 0 & 36 \\
Oct. & $15(27.27)$ & $17(30.91)$ & $17(30.91)$ & $6(10.91)$ & 0 & 55 \\
Nov. & $15(38.46)$ & $12(30.77)$ & $6(15.38)$ & $4(10.26)$ & $2(5.13)$ & 39 \\
Dec. & $15(34.09)$ & $11(25.00)$ & $8(18.18)$ & $9(20.45)$ & $1(2.27)$ & 44 \\
Total & $109(24.12)$ & $121(26.77)$ & $116(25.66)$ & $90(19.91)$ & $16(3.54)$ & 452 \\
\hline
\end{tabular}

TABLE II

Stomach fullness in different size groups (Carapace Width in mm) of Portunus pelagicus (L.)

\begin{tabular}{lcccccc}
\hline & \multicolumn{5}{c}{ Number $(\%)$} \\
\cline { 2 - 7 } Size class & Empty & $25 \%$ & $50 \%$ & $75 \%$ & Full & Total \\
\hline $61-80 \mathrm{~mm}$ & $6(40.00)$ & $1(6.67)$ & $4(26.67)$ & $4(26.67)$ & 0 & 15 \\
$81-100 \mathrm{~mm}$ & $43(31.62)$ & $28(20.59)$ & $36(26.47)$ & $23(16.91)$ & $6(4.41)$ & 136 \\
$101-120 \mathrm{~mm}$ & $36(21.43)$ & $49(29.17)$ & $41(24.40)$ & $34(20.24)$ & $8(4.76)$ & 168 \\
$121-140 \mathrm{~mm}$ & $13(18.06)$ & $23(31.94)$ & $19(26.39)$ & $16(22.22)$ & $1(1.39)$ & 72 \\
$141-160 \mathrm{~mm}$ & $9(19.57)$ & $12(26.09)$ & $13(28.26)$ & $11(23.91)$ & $1(2.17)$ & 46 \\
$161-180 \mathrm{~mm}$ & $2(13.33)$ & $8(53.33)$ & $3(20.00)$ & $2(13.33)$ & 0 & 15 \\
Total & 109 & 121 & 116 & 90 & 16 & 452 \\
\hline
\end{tabular}

The points of the major food groups (by size and by month) are given in figs. 1 and 2. In percentage of points, Crustaceans was the most dominant food group, and was found in $28.57 \%$ of the stomachs 'with food'. This fraction consisted primarily of decapods (parts of shrimps, like rostrum, parts of exoskeleton, appendages; and crab exoskeleton fragments, appendages, and eggs), and further contained the remains of amphipods, isopods, and stomatopods. In different size groups of crabs, the total of crustacean remains varied between 6.5 and $28.9 \%$.

The second dominant food item was 'molluscan remains', mainly comprising shell fragments of bivalves and gastropods. It ranged between 8.6 and $16.7 \%$ in the various size groups and the maximum percentage was observed in the 101$120 \mathrm{~mm}$ group. Fish remains formed the third most important food item. These were present in $15.42 \%$ of the stomachs. The percentage points of 'fish remains' 
TABLE III

Percentage of points and frequency of occurrence of major food groups in Portunus pelagicus (L.)

\begin{tabular}{lccc}
\hline Items & Points & \% of points & $\begin{array}{c}\text { \% of frequency } \\
\text { of occurrence }\end{array}$ \\
\hline Crustacean remains & 4844 & 28.57 & 78.43 \\
Molluscan remains & 2761 & 16.28 & 59.48 \\
Fish remains & 2614 & 15.42 & 56.27 \\
Miscellaneous & 3523 & 20.78 & 83.09 \\
Debris & 3215 & 18.96 & 79.59 \\
\hline
\end{tabular}

*Empty stomachs are not included in the total number of crabs.

varied between 2.4 and $30.8 \%$. Fish food dominated in the stomach contents of the larger size groups of the crab (141-160 and 161-180 mm).

The 'miscellaneous' group mainly comprised crushed polychaetes, plant material originating from seaweeds and sea grasses, etc. This group was present in the majority of the stomachs and varied between 19.2 and $42.5 \%$. Detritus was present

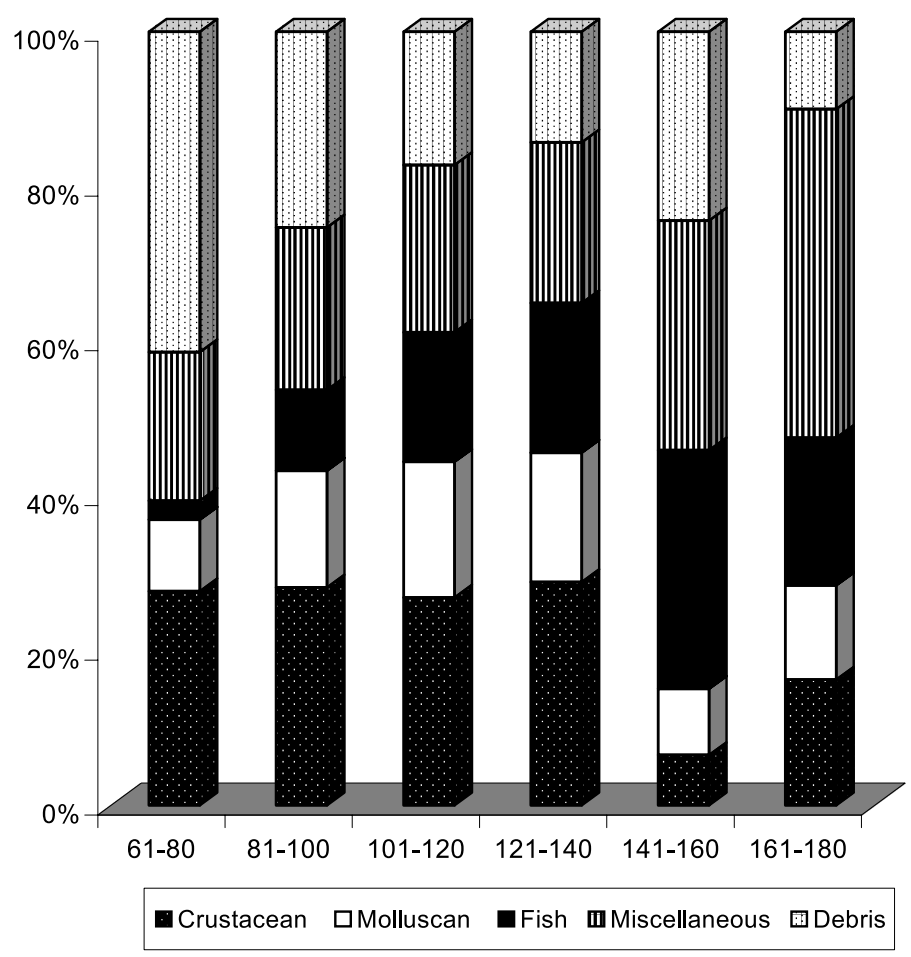

Fig. 1. Points of major food groups in various size groups of Portunus pelagicus (L., 1758). 


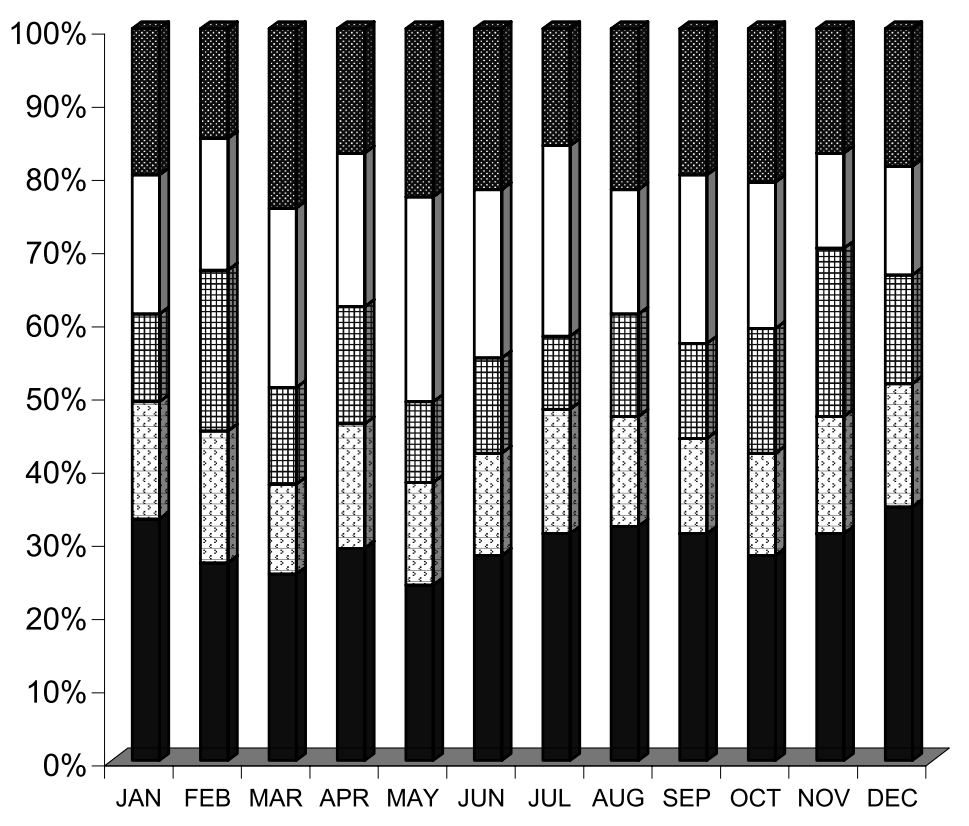

Crustacean $\square$ Molluscan 田 Fish $\square$ Miscellaneous 圆 Debris

Fig. 2. Points of major food groups during various months in Portunus pelagicus (L., 1758).

in $18.96 \%$ of the stomachs. Their percentages of points in the different size groups varied between 10.0 and $41.4 \%$.

Juvenile crabs $(<80 \mathrm{~mm} \mathrm{CW})$ appeared to prefer debris (41.4\%) followed by crustaceans (27.7\%), and miscellaneous items (19.2\%). In the subadult group (81$100 \mathrm{~mm} \mathrm{CW})$, crustaceans (28.2\%) were the major food item followed by debris $(25.3 \%)$ and miscellaneous $(21.0 \%)$. In adults $(100-140 \mathrm{~mm})$, crustaceans were the principal food item, whereas in the larger size group of adults $(141-180 \mathrm{~mm})$ fish and miscellaneous material constituted the main items of food.

\section{DISCUSSION}

The diet of Portunus pelagicus was found to be similar in several respects to the diet of other portunid crabs. They are all opportunistic omnivores with a preference for animal prey, but within that framework only rarely feed on more mobile prey such as fish and prawns (Patel et al., 1979; Williams, 1982). Warner (1977) was also of the opinion that crabs are opportunistic omnivores with a preference for animal food in conjunction with a definite predatory propensity. In the present study, it is observed that crustaceans constitute the most favoured item in this species' diet, followed by molluscs and fish. This conforms with the findings of 
Patel et al. (1979), while also Sukumaran \& Neelakantan (1997) reported that $P$. pelagicus from the Mangalore coast preferred crustaceans, but in that location followed by fishes and molluscs, respectively. Chande \& Mgaya (2004) reported that molluscs, particularly the bivalve Arcuatula arcuatula (Hanley, 1843), were the most important food items in the stomachs of $P$. pelagicus along the coast of Dar es Salaam, Tanzania. Al-Behbehani (2007), also reported that molluscs and crustaceans were the dominant food items in the stomachs of $P$. pelagicus from Kuwait waters.

The wide foraging strategy of $P$. pelagicus is also typical of other portunid crabs. All species studied so far have been reported to consume mixed diets of molluscs, crustaceans, fishes, and polychaetes, similar to P. pelagicus (e.g., Carcinus maenas (L., 1758): Ropes, 1968; Scylla serrata: Hill, 1976; Callinectes sapidus M. J. Rathbun, 1896: Laughlin, 1982; Scylla tranquebarica (F., 1798) and S. serrata: Joel \& Raj, 1986; S. serrata: Prasad \& Neelakantan, 1988; Thalamita crenata (H. Milne Edwards, 1834): Cannicci et al., 1996). The presence of detritus (79.59\%) in the stomachs examined suggests that these crabs are also detritivorous, consuming both fresh and decaying flesh of all kinds of animals, as observed in the present study. It was found that the stomachs of juveniles and sub-adults are predominated by debris. Menon (1952) and Patel et al. (1979) have reported the presence of fair amounts of organic matter mixed with sand, mud, gravel, and other bottom particles, which indicates the species' bottom feeding habits in its bottom habitat. The considerable amount of detritus in their guts has shown that P. pelagicus is also an opportunistic deposit feeder, just as reported by Prasad \& Neelakantan (1988) for Scylla serrata. The detrital energy assimilated by the crab population is thus converted partly into body tissues (Macintosh, 1984).

Many portunids also consume small quantities of macrophytes. The adults of Liocarcinus puber (L., 1767) are found to consume plant material (brown algae) even by preference (Choy, 1986). Grapsid, xanthid, majid, potamid, and portunid crabs (in portunids particularly juveniles) have also been reported to consume plant material (Hartnoll, 1963; Ropes, 1968; Hill, 1976; Warner, 1977; Paul, 1981; Jewett \& Feder, 1982; Williams, 1982; Rosas et al., 1994). In the present study, the stomach contents of juveniles and of sub-adult crabs contained semi-digested plant material, like remains of seaweeds and sea grasses.

There was no difference observed in the quantity of the food consumed by males and females, as also reported earlier by Williams (1981), Jewett \& Feder (1982), Sumpton \& Smith (1990), and Wieczorek \& Hooper (1995). Feeding generally takes place every day throughout the year, except in berried females and during the days of 'pre-moult' and mating, when feeding ceases or is at its minimum. The majority of crabs with empty stomachs encountered during the study were either in berried condition or in an advanced stage of 'pre-moult'. Choy (1986) also 
reported empty stomachs in gravid females and in parasitized crabs. Jewett \& Feder (1982) reported that feeding increases during spring in the king crab, Paralithodes camtschaticus. However, in Portunus pelagicus no such variation was observed, as India is, of course, a tropical country and consequently does not have such sharp seasonal differentiation. Balasubramanian (1993) reported that feeding intensity is comparatively low among adult Charybdis smithii MacLeay, 1838, found at the bottom. Jewett \& Feder (1983) concluded that small crabs feed more intensively than larger crabs, since moulting frequency among the smaller crabs is higher and thus their energy demand is higher as well.

It is not possible to deduce from stomach contents whether a prey item was alive or not when consumed. Caine (1974) had explained a prey catching mechanism in the portunid crab, Ovalipes guadulpensis Rathbun, 1930, but Hill (1976) was unable to observe such a technique in Scylla serrata. Prasad et al. (1985) have observed mud crabs catching live prawns in a prawn culture field during harvesting seasons. However, when adult $P$. pelagicus were reared in a hatchery along with juvenile shrimp of the species Penaeus semisulcatus De Haan, 1844, active predatory attempts were not observed (JJ, pers. obs.). Hence, the incidence of animal remains in the gut contents may indicate that the crabs might have opted for dead and decaying material by scavenging. Yet, the presence of crab exoskeleton matter in the stomach contents also shows that they are cannibalistic. Cannibalism was observed on several occasions in the rearing tanks, especially during moulting when the bodies of the newly moulted crabs are soft and vulnerable to attack by the hard-shelled crabs. In the present study, it was observed during several occasions that crabs were consuming the exuviae of other crabs. Hence there are ample chances that the crab remains recorded from the stomachs may be the result of cannibalistic consumption. Thus, the present study, as earlier related studies, suggests that, despite the diversity in crab diets and feeding habits, portunid crabs are opportunistic omnivores with a preference for animal food, also along the coast of Mandapam, India.

\section{ACKNOWLEDGEMENTS}

The author wishes to express her sincere gratitude to the Director, Central Marine Fisheries Research Institute, Cochin for his encouragements and providing the facilities for the research work. The author also records her sincere gratitude to Dr. J. C. von Vaupel Klein, managing editor of Crustaceana, for his help in editing the manuscript. 


\section{REFERENCES}

Al-Behbehani, B. E., 2007. Biological studies on the blue crab Portunus pelagicus and its parasitic infection in Kuwaiti waters. Journal of Egypt Society of Parasitology, 7(1): 215-225.

Balasubramanian, C. P., 1993. Studies on the deep water crab Charybdis (Goniohellenus) smithii MacLeay from the seas around India: 1-212. (Ph. D. Thesis, Cochin University of Science and Technology, Cochin, India).

BARKER, P. L. \& R. G. GIBSON, 1978. Observations on the structure of the mouth parts, histology of the alimentary tract and digestive physiology of the mud crab Scylla serrata (Forskål) (Decapoda: Portunidae). Journal of Experimental Marine Biology and Ecology, 32: 177-196.

BRYCESON, I. \& A. MASSINGA, 2002. Coastal resources and management systems influenced by conflict and migration: Mecufi Mozambique. Ambio, 31: 512-517.

CAINE, R. A., 1974. Feeding of Ovalipes guadulpensis and morphological adaptations to a burrowing existence. Biological Bulletin, Woods Hole, 147: 550-559.

CAmpBell, G. R., 1984. A comparative study of adult sexual behaviour and larval ecology of three commercially important portunid crabs from the Moreton Bay region of Queensland, Australia. (Unpubl. Thesis, University of Queensland, Brisbane, Australia).

Cannicci, S., F. Dahdouh-Guebas, D. Anyona \& M. Vannini, 1996. Natural diet and feeding habits of Thalamita crenata (Decapoda, Portunidae). Journal of Crustacean Biology, 16(4): 678-683.

Chande, A. I. \& Y. D. Mgaya, 2003. The fishery of Portunus pelagicus and the species diversity of portunid crabs along the coast of Dar es Salaam. Western Indian Ocean Journal of Marine Science, 2: 75-84.

— — \& — , 2004. Food habits of blue swimming crab Portunus pelagicus, along the coast of Dar es Salaam. Western Indian Ocean Journal of Marine Science, 3(1): 37-42.

Chande, A.I., A. M. Nikundiwe \& J. Kyomo, 1999. The status of the crab fishery at Mzinga Creek, Dar es Salaam. In: N. S. Jiddawi \& R. D. STANLEY (eds.), Fisheries and stock assessment in the traditional fisheries sector: the information needs: 81-87. (Proceedings of the National Workshop on the Artisanal Fisheries Sector, Zanzibar, Tanzania).

CHOY, S. C., 1986. Natural diet and feeding habits of the crabs Liocarcinus puber and L. holsatus (Decapoda, Brachyura, Portunidae). Marine Ecology Progress Series, 31: 87-99.

Dahdouh-Guebas, F., M. Giuggioli, A. Oluoch, M. Vannini \& S. Cannicci, 1999. Feeding habits of non-ocypodid crabs from two mangrove forests in Kenya. Bulletin of Marine Science, 64: 291-297.

Dall, W. \& D. J. W. Moriarty, 1983. Functional aspects of nutrition and digestion. In: D. E. Bliss \& L. H. MANTEL (eds.), The biology of Crustacea, 5, Internal anatomy and physiological regulation: 255-261. (Academic Press, New York).

George, M. J., 1965. The anatomy of the crab - Portunus sanguinolentus (Herbst). Part V. Digestive system. The Madras University Journal, 35: 83-95.

Hartnoll, R. G., 1963. The biology of Manx spider crabs. Proceedings of the Zoological Society of London, 141(3): 423-496.

HILL, B. J., 1976. Natural food, foregut clearance-rate and activity of the crab Scylla serata. Marine Biology, Berlin, 34: 109-116.

- -1980 . Effect of temperature on feeding activity in the crab Scylla serrata. Marine Biology, Berlin, 59(3): 189-192.

Hynes, H. B. N., 1950. The food of the freshwater stickle backs (Gastorosteus aculeatus and Pygosteus pungitius) with a review of methods used in studies of the food of fishes. Journal of Animal Ecology, 19: 36-58.

Jewett, S. C. \& H. M. Feder, 1982. Food and feeding of king crab Paralithodes camatschatica near Kodiak Island, Alaska. Marine Biology, Berlin, 66: 243-250. 
— — \& — - 1983. Food of the tanner crab Chionoecetes bairdi near Kodiak Island, Alaska. Journ. Crust. Biol., 3(2): 196-207.

JoEL, D. R. \& P. J. S. RAJ, 1986. Food and feeding of the two species of Scylla (De Haan) (Portunidae: Brachyura). Journal of the Marine Biological Association of India, 28(1-2): 178183.

Josileen, J. \& N. G. Menon, 2004. Larval stages of the blue swimmer crab, Portunus pelagicus (Linnaeus, 1758) (Decapoda, Brachyura). Crustaceana, 77(7): 785-803.

- $-\&-\ldots, 2005$. Growth of the blue swimmer crab, Portunus pelagicus (Linnaeus, 1758) (Decapoda, Brachyura) in captivity. Crustaceana, 78(1): 1-18.

KyOMO, J., 1999. Distribution and abundance of crustaceans of commercial importance in Tanzania Mainland coastal waters. Bulletin of Marine Science, 65: 321-335.

Laughlin, R. A., 1982. Feeding habits of the blue crab, Callinectes sapidus Rathbun, in the Apalachicola estuary, Florida. Bulletin of Marine Science, 32(4): 807-822.

Macintosh, D. J., 1984. Ecology and productivity of Malaysian mangrove crab populations (Decapoda: Brachyura). Proc. Asian Symposium on Mangrove Environment Research and Management: 354-377.

Menon, M. K., 1952. A note on the bionomics and fishery of the swimming crab Neptunus sanguinolentus (Herbst) on the Malabar coast. Journal of the Zoological Society of India, 4(2): 177-184.

NATARAJAN, A. V. \& A. V. JHINGRAN, 1961. Index of preponderance - A method of grading the food elements in the stomach analysis of fishes. Indian Journal of Fisheries, 8(1): 54-59.

Patel, N. M., N. D. ChHAYA \& Bhaskaran, 1979. Stomach contents of Portunus pelagicus (Linn.) from AD net catches. Indian Journal of Marine Science, 8: 48-49.

PAUL, R. K., 1981. Natural diet, feeding and predatory activity of the crabs Callinectes arcuatus and C. toxotes (Decapoda, Brachyura, Portunidae). Marine Ecology Progress Series, 6: 91-99.

Prasad, P. N., R. HonnaVar \& B. NeelaKantan, 1985. The mud crab Scylla serrata (Forskål) as a pest in the prawn culture fields adjoining Kali estuary, Karwar. Sea Food Export Journal, 17: 6-7.

Prasad, P. N. \& B. Neelakantan, 1988. Food and feeding of the mud crab Scylla serrata (Forskål) (Decapoda: Portunidae) from Karwar waters. Indian Journal of Fisheries, 35(3): 164170.

Ropes, J. W., 1968. The feeding habits of the green crab, Carcinus maenas (L.). Fishery Bulletin U.S. Fish Wildlife Service, 67: 183-203.

Rosas, C., E. Lazaro-Chavez \& F. Buckle-Ramirez, 1994. Feeding habits and food niche segregation of Callinectes sapidus, C. rathbunae and C. similis in a sub-tropical coastal lagoon of the Gulf of Mexico. Journ. Crust. Biol., 14(2): 371-382.

STEHLIK, L. L., 1993. Diets of the brachyuran crabs Cancer irroratus, C. borealis and Ovalipes ocellatus in the New York Bight. Journ. Crust. Biol., 13(4): 723-735.

Stephenson, W., D. C. Chant \& S. D. CoOK, 1982. Trawled catches in northern Moreton Bay. I. Effects of sampling variables. Memoirs of the Queensland Museum, 20: 375-386.

Stoner, A. W. \& B. A. Buchanan, 1990. Ontogeny and overlap in the diets of four tropical Callinectes species. Bulletin of Marine Science, 46: 3-12.

Sukumaran, K. K., 1995. Fishery, biology and population dynamics of the marine crabs, Portunus (Portunus) sanguinolentus (Herbst) and Portunus (Portunus) pelagicus (Linnaeus) along the Karnataka coast: 1-163. (Ph. D. Thesis, Karnataka University, Dharwad, Karnataka, India).

Sukumaran, K. K. \& B. Neelakantan, 1997. Food and feeding of Portunus (Portunus) sanguinolentus (Herbst) and Portunus (Portunus) pelagicus (Linnaeus) (Brachyura: Portunidae) along the Karnataka coast. Indian Journal of Marine Science, 26(1): 35-38.

Sumpton, W. D. \& G. S. Smith, 1990. Effect of temperature on the emergence activity and feeding of male and female sand crabs (Portunus pelagicus). Australian Journal of Marine and Freshwater Research, 41(4): 545-550. 
TagAtZ, M. E., 1968. Biology of the blue crab Callinectes sapidus Rathbun in the St. Jones River, Florida. Fishery Bulletin U.S. Fish and Wildlife Service, 67: 17-33.

WARNER, G. F., 1977. The biology of crabs: 1-202. (Van Nostrand Cy, New York).

Wassenberg, T. J. \& B. J. HiLl, 1987. Feeding by the sand crab Portunus pelagicus on material discarded from prawn trawlers in Moreton Bay, Australia. Marine Biology, Berlin, 95: 387-393.

WieczoreK, S. K. \& R. G. HoOPER, 1995. Relationship between diet and food availablity in the snow crab Chionoecetes opilio (O. Fabricus) in Bonne Bay, Newfoundland. Journ. Crust. Biol., 15(2): 236-247.

Williams, M. J., 1981. Methods for analysis of natural diet in portunid crabs (Crustacea: Decapoda: Portunidae). Journal of Experimental Marine Biology and Ecology, 52: 103-113.

— - 1982. Natural food and feeding in the commercial sand crab Portunus pelagicus Linnaeus, 1766 (Crustacea: Decapoda: Portunidae) in the Moreton Bay, Queensland. Journal of Experimental Marine Biology and Ecology, 59: 165-176.

First received 5 July 2010.

Final version accepted 8 June 2011. 